\title{
The Strategy of the Eurasian Economic Union Extra-Regional Integration
}

\author{
AGNIESZKA KONOPELKO \\ Department of Engineering Management \\ Bialystok University of Technology \\ 45A, Wiejska Street, Bialystok \\ POLAND \\ email: a.konopelko@pb.edu.pl \\ KATARZYNA CZEREWACZ-FILIPOWICZ \\ Department of Engineering Management \\ Bialystok University of Technology \\ 45A, Wiejska Street, Bialystok \\ POLAND \\ email: k.czerewacz@pb.edu.pl
}

\begin{abstract}
The main purpose of the research presented in the article is to answer the question of whether or not the Eurasian Economic Union has strategic opportunities to initiate integration processes with third countries and built comparative advantages. The authors identify the channels of its integration with third countries as well as assess their effectiveness based on the relationship with Vietnam, Singapore, Iran and China. The following methods were used: a critical literature analysis, an empirical analysis of the official documents, a logical construct method, an analytical theoretical overview of the Eurasian Economic Union external strategy, as well as statistical methods. Subsequently, based on the results obtained, a SWOT (Strengths, Weaknesses, Opportunities, Threats) analysis was carried out. The work diagnoses the main vectors of the Eurasian Economic Union strategy, analyses its institutional extra-regional integration as well as defines the scope and main channels of the influence of business and logistics on extra-regional integration. The main achievement of the research presented in the article is the diagnosis and assessment of the impact channels of Eurasian Economic Union extra-regional integration. The research points out that the organisation has an effective extraregional policy towards very different Eurasian countries and uses many channels of influence.
\end{abstract}

Key-Words: Eurasian Economic Union, China, Russia, logistics corridors, strategy, extra-regional integration Received: June 7, 2020. Revised: November 14, 2020. Accepted: January 5, 2021. Published: January 11, 2021

\section{Introduction. Conceptualisation of the problem}

Nowadays, regionalism may be an element of a state's strategy, build regional comparative advantages as well as or may determine the entire strategy for its economic and political development. As early as during the project phase, the Eurasian Economic Union (EAEU) was to become a remedy for a number of challenges and problems faced by the member states related to economic development, political relations and the challenges of the modern world. The first step towards establishing a new organisation was the establishment of a customs union in 2011 [1]. The Eurasian Economic Union began operating on 1 January 2015, integrating five countries: Armenia, Belarus, Kazakhstan, Kyrgyzstan and the Russian Federation. As a target, it is expected to lead member states to the economic union stage [2]. The EAEU is distinguished by its abilities to create external relations from other integration groups in the post-Soviet area. The integration concept of the EAEU itself not only concerns internal aspects but can take the form of an external strategy [3]. One could venture to say that an international strategy for the member states has been built into the EAEU concept.

In 2011, Vladimir Putin, President of the Russian Federation, declared in the newspaper 'Izvestia' that 'the Eurasian Union is an open project' and stated that the supranational organisation welcomed 'other partners to it, particularly CIS (the Commonwealth of Independent States) member states' [4].

In light of the so-called 'New Great Game' between China, the EU and the USA in Eurasia, the EAEUas one of the most important integration groups in this region-has been expanding its influence not only towards China, including the Belt and Road 
Initiative (BRI), but also towards closer or more distant partners such as Vietnam, Iran, Singapore, Serbia, India, Indonesia, Egypt, Israel, Cambodia, or Chile.

Such a multi-vector strategy of the EAEU and Russia in particular is perceived as a way to keep China's influence in Eurasia under control ([5]; [6]). The main purpose of the research presented in the article is to attempt to answer whether or not the Eurasian Economic Union possesses the strategic capacities to create integration processes with third countries. In addition, the authors took it upon themselves to identify EAEU integration channels with third countries and evaluate the effectiveness of these channels based on the example of the EAEU's relationship with four countries: Vietnam, Singapore, Iran and China.

Originally, the EAEU was supposed to play the role of a 'connecting element' between Europe and the dynamic Asia-Pacific region [4]. However, the EAEU was created in a very unfavourable period for the development of relations with the European Union. Russia's conflict with the Ukraine, which finally rejected membership of the EAEU in 2013, caused tense political relations and an economic embargo between the EU and Russia. The embargo was maintained in the following years, effectively preventing cooperation dialogue between the EU and the EAEU. In the first years of its functioning, the young organisation had to redefine its vectors of foreign cooperation. For this reason, the ability to strengthen relations with third countries has become a real test for the EAEU-all the more so because the possibility of strengthening relations with third countries will legitimise the EAEU as an integration grouping.

The main purpose of the research presented in the article is to attempt to answer whether or not the Eurasian Economic Union possesses the strategic capacities to create integration processes with third countries. In addition, the authors took it upon themselves to identify EAEU integration channels with third countries and evaluate the effectiveness of these channels based on the example of the EAEU's relationship with four countries: Vietnam, Singapore, Iran and China.

The contribution is significant because it covers an important but previously neglected research area new regional organisation Eurasian Economic Union and new aspects and vectors of its external relations with third countries. The article presents a new interdisciplinary approach to the issues of regional economic integration namely the evaluation of the scope and impact of institutional and business capacities of the EAEU extra-regional integration.
The previous analyses on intra-regional and interregional channels of integration have been expanded by an analysis and estimation of extra-regional decisions and activities. The research reveals new tendencies in diversification of the EAEU external strategy (new cooperation formats), redirection of its institutional extra-regional integration towards new external partners (Vietnam, Iran, Singapore, Serbia) to balance the growing of China's influence and a new strategy for transcontinental transport corridors. The areas studied in the article may constitute significant comparative advantages of the EAEU and affect business relations in Eurasia

\section{Literature review}

In the literature on the subject, one can identify studies on the characteristics of integration in the post-soviet area, the phenomenon of integration within the EAEU, external relations of the EAEU, the possibility of the EAEU participation in the BRI. In addition, a separate area of analysis is the position that treats the EAEU as a grouping between China and the EU [7].

Libman and Vinokurov note that integration in the post-Soviet area is intended to ensure the halting of the disintegration process and enable the maintenance of some of the connections which were beneficial for the countries of the region during the Soviet period [8]. This type of integration was even called 'holding-together regionalism' by authors to emphasise its rarity and distinctiveness. The premises for integration processes in the research area are largely of a political nature, thus, some researchers perceive them in the context of Russia's attempt to change the order of the modern world and create a multipolar world [9] in the contexts of the USA, China and the European Union. On the other hand, the countries of the post-Soviet area seek factors favouring their economic development and fuelling their economies in the processes of international integration [8]. The forces of regionalism, however, play a key role in shaping the international trading system [10].

The concept and subsequent implementation of the Eurasian Economic Union forced a revision of some views on the processes of international regional integration in the post-Soviet area. Many researchers see new qualitative features in this initiative, despite claims that the EAEU is another attempt to strengthen Russia's position in the region. Writing about the EAEU, Dragneva and Wolczuk emphasise that this is a new type of project, with ambitions to bring measurable benefits to their 
member states and to be a visible alternative to the European Union [11].

The Eurasian Economic Union therefore has a chance not only to qualitatively develop new effects within intra-regional integration, but also to become an effective instrument in external relations.

This means that the BRI is an attractive formula for many countries when it comes to shaping their international relations. However, as the BRI is not a classic integration group and does not have any instruments for institutionalising mutual relations, bilateral relations also dominate in this context. From the perspective of the countries researched, it is possible to use the instruments offered by the EAEU to shape relations within the BRI [7], and thus to use extra-regional relations.

Inter-regional cooperation covers relations between regional groupings, however, most researchers also include relations between regional groupings and external individual countries here. Examples of inter-regional cooperation are as follows: the Belt and Road Initiative, ASEM, APEC, EUMERCOSUR, EU-ACP, EU-NAFTA, NAFTAMERCOSUR, ASEAN-MERCOSUR, EAEU-UE, EAEU-ASEAN, and EAEU-MERCOSUR. The main objectives of such integration focus on the extension of integration processes, such as free trade areas and deepening the existing cooperation agreements.

Similarly, research on extra-regional integration processes refers to issues such as the influence of external partners (regional groupings and individual countries) on regional integration and the existing asymmetries between the partners involved in such model of integration [12].

Wooster, Tepa and Smile define extra-regional trade as trade between the organisation and non-member countries [13], in contrast to intra-regional trade among its member states. Such complex interdependences between extra-regional integration and intra-regional cooperation have been widely described by Krapohl and Vasileva-Dienes [14] and Czerewacz-Filipowicz and Konopelko [15].

\section{Methods}

The Eurasian Economic Union employs various instruments of institutional external influence in its foreign strategy, such as: non-preferential agreements on economic and trade cooperation (with China), free trade agreements (with Vietnam, Iran, Singapore and Serbia), granting observer status (to Moldova), memorandums of understanding (with the ASEAN, Bangladesh, Cambodia, Chile, the CIS, the EU Committee for Standardisation, and
Singapore) and memorandums on cooperation (with Cuba, Ecuador, Indonesia, Jordan, MERCOSUR, Mongolia, Morocco, Peru, South Korea, and Thailand).

The authors focused on certain aspects of extraregional integration of the EAEU, namely institutional and business (economic) relations between the Eurasian Economic Union and selected third countries with the most advanced integration processes, starting with the creation of the EAEU to the present day. Therefore, the authors carried out an analysis of the EAEU's free trade agreements and cooperation agreements with China, Iran, Vietnam, and Singapore and business and logistics bilateral relations which enabled them to evaluate the strategic channels and capacities of EAEU extraregional integration on the basis of a SWOT analysis.

An important part of the research was a descriptive analysis of the EAEU's basic legal documents (treaties, decisions and declarations) which allowed the researchers to define and outline the scope and key vectors of EAEU external strategy.

An integral part of the research was an analysis of the EAEU's ability to support and develop business relationships between entities from member states as part of external-integration relations. The researchers wanted to check whether the contracts concluded cause business effects. For this purpose, trade effects for EAEU countries resulting from the conclusion of free trade agreements and cooperation agreements by the EAEU were researched. An important element included in the study were the transport corridors developed by the EAEU and the Logistics Performance Index (LPI). Logistics conditions have been taken into account because the EAEU has ambitions to play an important role within the Belt and Road Initiative and as a bridge between the countries of Eurasia. In connection with the above, the following question arose: what elements could the bridge be based on? It seems that it can mainly be based on the favorable conditions of the EAEU connected with geographical location and possibilities of developing logistics corridors in transcontinental relations.

A turning point of the research concerns the period from 2011, i.e. the year in which the first steps were taken to activate the mechanisms of the impact of the EAEU, in particular the functioning of the customs union.

Individual trade and logistics indicators were researched based on a bilateral approach, i.e. they were analysed separately for each of the member states. Thanks to this, it was possible to determine whether similar effects occur in all the EAEU 
countries despite the differences in their size and economic potential.

The choice of external-integration directions was dictated by the stage of completion of individual contracts. This includes the most advanced free trade agreements and economic cooperation agreements signed by the EAEU. The studies deliberately included very different countries. This made it possible to assess the strength of externalintegration of the EAEU.

\section{Vectors of EAEU external strategy}

Domestic political institutions and decision-makers determine the level and the scope of regional institutional integration processes in their foreign strategies [16]. Decisions on strategic directions of the external relations and foreign policy of the EAEU are highly connected with the individual policies of particular member states, due to the highest EAEU body authorised to outline strategic decisions is the Supreme Eurasian Economic Council-comprised of the heads of the stateswhereas the Eurasian Economic Commission is involved in the entire negotiation process in terms of the final arrangements [1]. Therefore, they should be perceived as a result of all various interests and needs; but the question is whether or not they really are, in the context of remaining asymmetries between the member states.

One of the main objectives of the EAEU, as outlined in Russia's Foreign Policy Concept launched in 2016, is Russian leadership in integration processes within Europe and Eurasia and the creation of 'a common economic and humanitarian space from the Atlantic to the Pacific by harmonizing and aligning interests of European and Eurasian integration processes' [17].

The basic legal document of the EAEU, the Treaty on the Eurasian Economic Union [18], outlines the general framework for EAEU international cooperation with other countries and international organisations on the basis of mutual benefits and equality. It is worth noting that the Eurasian Economic Commission, in its Decision on 'The main directions of the EAEU's economic development until 2030' signed in 2015 [19], indicates traditional forms of international integration such as preferential and non-preferential trade agreements to diversify trade flows and reduce transaction costs; whereas the Commission, in its 2018 Declaration on further development of integration processes within the Eurasian Economic Union [20], provides 'new cooperation formats' as the basis for economic relations with the external partners that will be developed in a future strategic directions for the development of Eurasian economic integration until 2025.

The 'new cooperation formats', defined by Molchanov as a new approach to regionalism supporting international competitiveness [21], reveal themselves in a multi-format dialogue with external partners by granting Observer State status at the EAEU, carrying out inter-regional cooperation with ASEAN, the EU, MERCOSUR, the OECD, the SCO and interacting with the UN and the WTO. Such instruments of EAEU external strategy are supposed to include the organisation in the global economy, diversify export partners, attract foreign investors, develop transport and logistics infrastructure and expand the EAEU's presence in international institutions ([20]; [22]).

The EAEU 2018 Declaration confirmed the idea of the 'Greater Eurasian Partnership' formulated in 2016 by Russian President Vladimir Putin. The concept replaced the previous ideas of 'Greater Asia' from Shanghai to Saint Petersburg and 'Greater Europe' from Lisbon to Vladivostok [23]. In light of the new idea, the EAEU was supposed to be a 'centre of gravity' of Greater Eurasia [24] that integrates the Eurasian continent through closer trade, economic and logistics ties between the EAEU, the Shanghai Cooperation Organisation and ASEAN, and attracts other potential economic partners as well ([25]; [26]).

In November 2017, during the APEC Economic Leaders' Summit in Vietnam, President Vladimir Putin confirmed the concept of the Greater Eurasian Partnership based on the EAEU and China's Belt and Road Initiative, stressing that the project would be open to other new participants [27].

\section{Analysis of EAEU institutional extra-regional integration}

Institutional form of regional integration pertains to legal and political decisions that may create and develop regional economic cooperation [15]. Thus, institutional extra-regional integration refers to the legal and political framework for closer economic cooperation between regional integration grouping and individual non-member country.

Currently, more than 50 countries or integration groupings have expressed their interest in closer integration with the Eurasian Economic Union [17], however, the forms and stages of extra-regional or inter-regional cooperation depend on the advancement of mutual negotiations and the common objectives and particular interests outlined 
in negotiation processes. The most advanced form of EAEU extra-regional integration is free trade agreements. Undoubtedly, such a kind of international agreements are to remove existing trade barriers and improve mutual economic effectiveness [28].

The EAEU has already signed free trade agreements with four countries. First agreement with Vietnam was concluded on 29 May 2015. Subsequent free trade agreements with other external partners were signed in 2018 and 2019. On 17 May 2018 the EAEU reached an agreement with Iran, on 1 October 2019 with Singapore and on 25 October 2019 with Serbia. Moreover, the EAEU signed a non-preferential Agreement on Economic and Trade cooperation with China on 17 May 2018 and Moldova obtained the status of observer to the EAEU on 14 April 2017. The instruments of external influence most often employed by the EAEU are memorandums of understanding (with the ASEAN, Bangladesh, Cambodia, Chile, the CIS, the EU Committee for Standardisation, and Singapore) and memorandums on cooperation (with Cuba, Ecuador, Indonesia, Jordan, MERCOSUR, Mongolia, Morocco, Peru, South Korea, and Thailand).

In order to 'create favourable conditions for the development and diversification of trade', the EAEU signed the first free trade agreement on 29 May 2015 with Vietnam [29]. The agreement provides for a wide range of tariff commitments, the schedule for their reduction or elimination within the period of 2016-2025, and reduces non-tariff barriers and simplifies customs formalities as well.

The core objective of the EAEU and Iran as defined in their provisional free trade agreement, namely to form a full-scale free trade area and work towards further trade and economic integration by means of the reduction or elimination of tariff and non-tariff barriers, seems to be typical of such agreements. However, from the perspective of deepening integration with the global economy, the second key objective, which is to support the earliest accession to the WTO of Iran and the EAEU states that are not currently WTO members, would be a milestone in their mutual relations [30].

The EAEU and China Agreement on Economic and Trade Cooperation, concluded on 17 May 2018, does not represent a classical model of agreement on a free trade area as many analysts recognise it. The main objective is to 'establish a basis for further development of economic relations between the Parties ... and 'facilitate trade in goods between the Parties by preventing and eliminating unnecessary (technical) barriers to trade', however, it does not directly provide for the abolition of tariffs and other non-tariff trade barriers [31]. Additionally, both sides confirmed they will aim for stronger cooperation between the EAEU and the BRI initiative, which according to Veronika Nikishina, the Minister in charge of Trade of the Eurasian Economic Commission, is "the optimal format for "launching" the coupling of the EAEU and the Belt and Road Project' [32].

In September 2019, negotiations on the conclusion of a free trade agreement between the EAEU and Singapore were finished, and the document was signed on 1 October 2019. The agreements on trade in services and investment will be concluded separately by individual EAEU members with Singapore [33].

The agreement on a free trade area provides for a wide range of tariff commitments, the schedule for their reduction or elimination within a period of 11 years starting with the year 2019, and reduces nontariff barriers and simplifies customs procedures [34].

As may be noted, the EAEU has accelerated its negotiations with new potential partners. Despite the complicated geopolitical situation in the region and other external determinants, further expansion is not impossible. Negotiations on future FTA agreements of the EAEU are underway with Israel, India, Egypt, Indonesia, Mongolia, Thailand, Tunisia, South Korea, Cambodia, and Chile, and likewise with other regional groupings-namely the ASEAN and the MERCOSUR.

\section{Logistics and business aspects}

In the case of the EAEU, trade connections are not easy to analyse. This applies to both commercial relations within the grouping as well as external relations. The countries that make up the grouping differ significantly in terms of economic and structural conditions. This results in a different power of influence of these countries in internal and external relations [15].

Business relationships of the EAEU members with third countries can be analysed in respect of trade flows. However, in the case of the researched area, the effectiveness of logistics processes being carried out in this area is also becoming important. The EAEU aspires to become a link between the countries of Asia and Europe. The key to fulfilling these aspirations is the transcontinental transport routes and related international logistics hubs that shape the links with third countries.

Trade flows between the individual EAEU countries and the third countries included in the survey 
showed certain patterns in 2011-2018. In the case of the Russian Federation, exports to Vietnam have increased significantly. There were also increases in Russian exports to Singapore and China. Russia also recorded an increase in imports from all third countries included in the study, i.e. China, Iran, Vietnam and Singapore. In the case of Kazakhstan, exports to Vietnam and Singapore increased. The increase in exports to Singapore was also noticeable in the case of Belarus. In this country, the high dynamics of import growth from China is also constantly maintained. Kyrgyzstan has significantly increased its exports to Iran. As for the structure of imports of this country, China has been the most important partner for several years. In turn, Armenia increased its imports from Vietnam and Iran during the period considered ([35]; [22]).

Logistically, the EAEU may take advantage of a number of its assets. Thanks to the EAEU, wares transported by land between the EU-China, Japan or, across the Caspian Sea, Iran, only cross two customs borders. Three economic corridors of the Belt and Road Initiative run through the EAEU: China-Mongolia-Russia, China-Central Asia-West Asia, the New Eurasia Land Bridge (the Belt and Road Initiative, China-Trade-Research - the Hong Kong Trade Development Council). In addition, Kazakhstan's Khorgos has a large international logistics center that handles transactions between the EAEU countries, China and the Middle East countries, including Iran. The China-Central Asia, East Asia transport corridor that connects China with the Arabian Peninsula runs through the Eurasian Economic Union. The corridor begins in Xinjang and through Central Asia reaches the Persian Gulf, the Mediterranean and the Arabian Peninsula. Its route passes through two countries of the EAEU: Kazakhstan and Kyrgyzstan and 17 countries and regions of Central Asia. Due to the possibility of transporting raw materials from the Arabian Peninsula, Turkey and Iran to Xinjang [36], it is of great importance to China.

As part of the integration within the EAEU, a number of measures have been taken to improve international transport corridors and improve their logistic efficiency. One of the most important activities was the introduction of the Customs Code of the EAEU, which significantly improved customs and border procedures. The document also imposed time limits for carrying out all formalities at the external borders of the EAEU ([37]; [38]).

Other activities are also underway to improve the efficiency of international transport corridors in the EAEU territory mainly: electrification, modernisation and revitalisation of rail routes (e.g. modernisation of the Trans-Siberian railway and the entire New Eurasian Land Bridge Economic Corridor), construction of new roads routes and development of existing ones (e.g. M6 motorway), as well as investments in logistics centres (e.g. Khorgos). These activities are reflected in the EAEU (LPI) Logistics Performance Index. In 20102018, Russia's position improved in the LPI rank from 94 position to 75 position, and the Infrastructure rating increased from 2.38 points to 2.78 points. Kazakhstan has seen a spectacular improvement in its LPI ranking. The country's position improved from 133 position in 2007 to 71 position in 2018. ([39]; [22]). However, the EAEU countries still face a number of challenges related to land transcontinental transport corridors, such as bottlenecks on the border with the EU [40]. Solving these problems could have a beneficial effect on extra-regional integration the EAEU.

\section{SWOT analysis}

Based on previous research on EAEU institutional and business extra-regional integration, we have applied the SWOT matrix in presenting an analysis which evaluates the strengths and weaknesses of the EAEU capacities for extra-regional integration and outlines the suggested opportunities and threats that may appear in its external environment (Table 1).

Observing the political regimes of selected third countries that expressed their willingness to cooperate with the EAEU, we can summarise that according to the Freedom House 'Freedom in the World 2019' report, practically one-third of the EAEU external partners were qualified as 'free' countries, one-third obtained 'partly free' status and one-third were ranked as 'not free' [41], thus, 15 of 21 potential external partners were recognised as not fully democratic regimes. On the one hand, such similarities (the so-called 'domino effect') are typical for deepening regional integration processes due to the lack of political obstacles; but on the other hand, such a vision may discourage the development of democratisation processes within the organisation and the creation of new ties with external democratic regimes including the European Union organisation, as well.

Diversified top-down external-regional integration linked with inter-regional initiatives is a challenge for EAEU decision-makers, especially in the context of the current geopolitical external environment. However, in view of the lack of a clear, coherent long-term strategy of external policy, it may result in strengthening the individual decisions made by member states towards the external partners, deepening the existing asymmetries and weakening 
the organisation as a whole. Such a scenario combined with possible intraregional geopolitical threats is an opportunity for China to strengthen its position in the region in terms of economics and security. On the one hand, new transport corridors and logistics centres may foster regional economic development, and on the other hand induce the economic dependence of the EAEU area on China. The EAEU is the first organisation in the postSoviet area that actually has bodies typical of an international organisation with the competence to sign international agreements with third countries, and uses these possibilities effectively. The Eurasian Economic Union has filled a void in international relations in a globalised world. Thanks to the creation of the EAEU, it is theoretically possible to standardise logistics, economic and business procedures over a very wide geographical area of Eurasia. The geographical location and size of the EAEU make the grouping a very attractive partner in terms of stronger cooperation for all Eurasian countries. Transport corridors running through the EAEU connect the EU, China, India and many other countries. In turn, the development of logistics centres such as Khorgos allows for the elimination of a number of logistical problems (e.g. different track gauges). For this reason, the EAEU can be a good business partner not only for China but also for Iran, Vietnam or Singapore. Even if it is not the final market for goods produced by these countries, they can use the EAEU as a distribution centre or transit route. All the more reason why logistics centres created within the EAEU (Khorgos, Great Stone) can be a chance to develop extra-regional integration. They can play an important role in the distribution of goods and services in Central Asia, at the meeting-point of the EU and the EAEU as well as at the EAEU-China border, which is important for many countries including the three which are among the four countries researched.

Table 1. EAEU SWOT Matrix of the capacities for extra-regional integration

\begin{tabular}{|l|l|}
\hline \multicolumn{1}{|c|}{ Strengths } & \multicolumn{1}{c|}{ Weaknesses } \\
\hline - $\begin{array}{l}\text { Inclusion of other various external partners } \\
\text { (close and distant neighbours) in integration } \\
\text { processes }\end{array}$ & - $\begin{array}{l}\text { Lack of clear, coherent and long-term vision } \\
\text { of strategy on the EAEU external policy } \\
\text { Dependence of the decision-making process } \\
\text { of the entire organisation on one prevailing } \\
\text { economy (China, India) }\end{array}$ \\
entity
\end{tabular}




\section{initiative)}

- Democratisation of political systems (increasing credibility of the member states among the potential partners and facilitating political dialogue with European Union)

- Stabilisation of geopolitical situation in the region (the examples of frozen conflicts and trans-border tensions)

- Membership of most EAEU countries in the WTO

- Global logistics centres (e.g. Khorgos; Great Stone) emerging in the EAEU countries and the Caucasus regions (possible

destabilization of integration initiatives inside and outside the organisation)

- Strengthening individual ambitions of particular political leaders and the position of particular member states and strengthening their bilateral relations with external countries (weakening the organisation as a whole)

- Reduction of China's support for transcontinental land rail and road transport corridors

- Deepening crisis in Russia's relations with Western countries

- A possible international financial and oil market crisis especially in the context of the COVID-19 pandemic

Source. Own elaboration

However, the bottlenecks on the border between the EAEU and the EU are a problem which reduces the business attractiveness of the transcontinental transport corridors running across the EAEU, especially from the Chinese perspective. Besides, it is not only the EU and the EAEU border bandwidth which is a problem, but also the lack of agreement and regulations between the two groupings. This significantly increases costs and extends the time spent at the border between the EU and the EAEU and generates a number of problems, e.g. the different length of trains in the EU and the EAEU causes a problem with crossing the border and checking them on the EU side. A weakness of the EAEU is its high dependence on the level of commodity prices and high sensitivity to economic crises. In addition, a real threat that would reduce the attractiveness of the EAEU as a business partner for many Eurasian countries would be limiting China's support for the construction of land transport routes to the EU. This is not just about financing investments but also about reducing the total amount of Chinese rail transport subsidies.

Additionally, new threats related to the COVID-19 pandemic exacerbated the economic slowdown in Russia and Kazakhstan, the strongest economies of the EAEU and affected their trade, investment and transport relations with China. Thus, one of the future challenge will be the process of debottlenecking of the existing constraints in the EAEU external relations.

\section{Results and discussion}

The idea of the greater post-Soviet area rooted in tradition, history and mentality evolved into the concept of the Greater Eurasian Partnership on the basis of the Eurasian Economic Union and the BRI initiative. However, Russia and its flagship EAEU project have opened the 'doors of integration' to new external partners to balance the growing influence of China's initiatives in the region.

The legally recognised institutional instruments of the EAEU organisation allow its decision-makers to create multi-vector integration processes with external partners. Following the key vectors outlined in the EAEU's external policy strategy, the organisation has intensified its institutional integration decisions towards new subsequent partner countries, revealed in new free trade agreements but also in new cooperation formats, such as the EAEU inter-regional cooperation with ASEAN or MERCOSUR. In general, it is hard to point out the common criterion to the selection of particular partner-countries. Definitely it can be said to move beyond geographical reach; however, the Eurasian direction is dominant. Furthermore, the more China represents stronger economic power, the more the other external partners- Vietnam, Iran, Singapore or Serbia-do not belong among the strongest global economies.

The Eurasian Economic Union was to connect Europe and Asia economically, and first of all in terms of logistics, including infrastructure. However, the creation of this initiative took place during the unfavourable period of the RussianUkrainian conflict and the mutual embargo between Russia and the EU. The intertwining of geopolitical and geo-economics conditions meant that it has become impossible to work out a plane of cooperation between the EU and the EAEU. However, research has shown that the EAEU has been able to effectively strengthen bonds within the 
framework of extra-regional integration at business, logistics and economic levels. An analysis of the logistics plane shows that positive effects within the researched free trade agreements and economic cooperation agreements are not only the result of favourable structural conditions of the EAEU countries but the activities of the organisation itself. When it comes to international relations, the EAEU is an attractive alternative due to structural factors. Undoubtedly, the establishment of the structure filled a certain void in terms of creating extraregional integration. From the perspectives of China, Iran, Vietnam and Singapore, it is better to set rules with the entire grouping.

In particular China, pushing the BRI concept, should value the EAEU, which can comprehensively solve infrastructure as well as logistics problems along the entire route between China and the EU.

It seems that the extra-regional integration of the EAEU may positively affect its intra-regional integration due to the possibility of extending the external sales markets in Eurasia and in other regions. According to Tigran Sargsyan, Chairman of the Board of the Eurasian Economic Commission 'the external track also bears growth potential' [32]. Still, the question is whether new cooperation formats may or may not weaken the existing regional economic ties and political interdependences.

From the perspective of many Asian and European countries, the Eurasian Economic Union has a chance to play a significant role and fill the gap not only in the context of transcontinental transport networks, but energy needs as well. A long-term goal may be electricity exports from the EAEU countries to foreign markets-European, Asian, and post-Soviet countries [42].

The embargo and the tense situation between the EU and Russia have probably influenced the EAEU's greater interest in establishing and strengthening extra-regional integration. However, if the EU and the EAEU are not going to work out a common platform for cooperation, this can also cast a shadow on relations between the EAEU and some Asian countries.

The EAEU in its 2018 Declaration on further development of integration processes within the Eurasian Economic Union confirmed its will to develop integration processes within the organisation but it didn't prepare a long-term strategy of external cooperation. Moreover, most of the EAEU's cooperation agreements were signed in 2018 and 2019, thus, it seems too early to outline and evaluate effects of the EAEU extra-regional integration. A proper assessment of the application of the EAEU in terms of extra-regional integration strategy will only be possible in the longer run. Effectiveness in establishing extra-regional agreements may be one of the elements of this strategy, however, the effects regarding closer cooperation should be waited. The Vietnam case can be a good measure however it cannot be a basis for making final conclusions on the EAEU extraregional strategy.

\section{References:}

[1] Vinokurov E (2018) Introduction to Eurasian Economic Union. Palgrave Macmillan, Cham.

[2] Dogovor o Jevrazijskom ekonomiczeskom sojuzie [Treaty on the Eurasian Economic Union] (2014). https://docs.eaeunion.org/ruru/Pages/DisplayDocument.aspx?s=bef9c798-

3978-42f3-9ef2-d0fb3d53b75fandw $=632 \mathrm{c} 7868$ 4ee2-4b21-bc64-1995328e6ef3andl=540294aec3c9-4511-9bf8-

aaf5d6e0d169andEntityID=3610. Accessed 6 Mar 2020020

[3] Czerewacz-Filipowicz K (2016) Regionalizm i regionalizacja w Euroazjatyckiej Unii Gospodarczej. Wpływ EAUG na integrację handlową państw członkowskich z gospodarką światową [Regionalism and regionalization in the Eurasian Economic Union. The influence of the EAEU on trade integration of the Member States into the world economy]. University of Technology Publishing House, Bialystok

[4] Putin V (2011) Novyj integracionnyj projekt dlja Jevrazii - buduščeje, kotoroje roždajetsja segodnja. Izvestija, 3 October. https://iz.ru/news. Accessed 2 Dec 2019

[5] Trenin DV (2017) Russia's Evolving Grand Eurasia Strategy: Will It Work? 20 July. https://carnegie.ru/2017/07/20/russia-sevolving-grand-eurasia-strategy-will-it-workpub-71588. Accessed 13 Dec 2019

[6] Köstem S (2019) Russia's Search for a Greater Eurasia: Origins, Promises, and Prospects. Kennan Cable No. 40. Wilson Center. Kennan Institute

[7] Kondybayeva S, Sadykhanova G, Mukhamediyev B (2017) The New Silk Road Economic belt policy: The great chance for the rejuvenation of Europe, Proceedings of the 29th International Business Information Management Association Conference - Education Excellence and Innovation Management through Vision 2020: From Regional Development 
Sustainability to Global Economic Growth: pp. 1969-1974

[8] Libman A, Vinokurov E (2012) HoldingTogether Integration: 20 Years of the PostSoviet Integration. Palgrave Macmillan, London

[9] Makarychev A, Morozov V (2011) Multilateralism, Multipolarity, and Beyond: A Menu of Russia's Policy Strategies. Glob Gov Rev Multilater Int Organi 17(3):353-373

[10] Kim J (2003) Sub-regionalism, regionalism, trans-regionalism. Implications for economic integration and international trade policies. Asia Eur J 1:183-196

[11] Dragneva R, Wolczuk K (2017) The Eurasian Economic Union Deals, Rules and the Exercise of Power. Chatham House, the Royal Institute of International Affairs, London

[12] Omonkulov O, Baba G (2019) Regional Integration via Major Powers: Russian Eurasian Economic Union versus Chinese Silk Road Economic Belt versus American New Silk Road Project. COMU Int J Soc Sci 4(1):1-28

[13] Wooster R, Tepa B, Smile D (2008) The Contribution of Intra-Regional and ExtraRegional Trade to Growth: Evidence from the European Union. J Econ Integr 23(1):161-182

[14] Krapohl S, Vasileva-Dienes A (2019) The region that isn't: China, Russia and the failure of regional integration in Central Asia. Asia Eur J. https://doi: 10.1007/s10308-019-00548-0

[15] Czerewacz-Filipowicz K, Konopelko A (2017) Regional Integration Processes in the Commonwealth of Independent States. Economic and Political Factors. Springer Publishing, Cham

[16] Konopelko A (2017) The impact of legal and political determinants on the regional economic integration between the members of the EAEU. In: Potocan V, Kalinic P, Vuletic A (eds), Economic and Social Development. Varazdin Development and Entrepreneurship Agency, Zagreb, pp 297-307

[17] Alekseenkova ES, Glotova IS, Devyatkov AV et al. (2017) EAEU development prospects Up to 2025. Russian International Affairs Council. Working Paper

[18] United Nations (2014) Preamble and art. 7 of Treaty on the Eurasian Economic Union of May

https://www.un.org/en/ga/sixth/70/docs/treaty_o n_eeu.pdf. Accessed 19 Nov 2019

[19] Eurasian Economic Commission (2015) The Main Directions of the EAEU's Economic Development until 2030. Decision No. 28/2015. http://www.eurasiancommission.org/ru/act/integ
r_i_makroec/dep_makroec_pol/seminar/Docum ents.pdf. Accessed 20 Sept 2019

[20] Eurasian Economic Union (2018a) Declaration on further development of integration processes within the Eurasian Economic Union. https://docs.eaeunion.org. Accessed 19 January 2020

[21] Molchanov MA (2018) The Eurasian Economic Union. In: Tsygankov AP (ed) Routledge Handbook of Russian Foreign Policy. Routledge, London and New York, pp 410-420

[22] Czerewacz-Filipowicz K, Konopelko A (2020) Can the EAEU Deliver External Integration to Business? Eur Res Stud J XXIII(2):515-528

[23] Konopelko A (2018) Eurasian Economic Union: a challenge for EU policy towards Kazakhstan. Asia Eur J 6(1):3

[24] Korosteleva E, Paikin Z, Paduano S (2019) Five Years After Maidan: Toward A Greater Eurasia? London School of Economics and Political Science, London

[25] EDB Centre for Integration Studies (2019) Eurasian Economic Integration-2019. Report 52, Moscow

[26] Alimov R (2018) The Shanghai Cooperation Organisation: Its role and place in the development of Eurasia. J Eurasian Stud 9:114124

[27] Russia Briefing (2017) Russia to Push Greater Eurasian Partnership Concept at APEC. Russia Briefing. 9 November. https://www.russia-briefing.com/news/russiapush-greater-eurasian-partnership-conceptapec.html. Accessed 3 Dec 2019

[28] Wei D, Chen Z, Rose A (2019) Estimating economic impacts of the US-South Korea free trade agreement, Econ Systems Res 31(3):205206

[29] Eurasian Economic Union (2015) Free Trade Agreement Between the Eurasian Economic Union and Its Member States, of the One Part, and the Socialist Republic of Viet Nam, of the Other Part. https://docs.eaeunion.org/docs/enus/0147849/iatc_02062015. Accessed 4 Dec 2019

[30] Eurasian Economic Union (2018b) Interim Agreement Leading to Formation of a Free Trade Area Between the Eurasian Economic Union and Its Member States, of the One Part, and the Islamic Republic of Iran, of the Other Part. https://docs.eaeunion.org/docs/enus/01417815/iatc_21052018. Accessed 10 Feb 2020 
[31] Eurasian Economic Union (2018c) Agreement on Economic and Trade Cooperation Between the Eurasian Economic Union and Its Member States, of the One Part, and the People's Republic of China, of the Other Part. https://docs.eaeunion.org/docs/en-

us/01417817/iatc_21052018. Accessed 11 Feb 2020

[32] Eurasian Economic Commission (2019) http://eec.eaeunion.org/en/nae/news/Pages/1012-2019-5.aspx. Accessed 20 Mar 2020

[33] Eurasian Economic Union (2019a) Framework Agreement on Comprehensive Economic Cooperation Between the Eurasian Economic Union and Its Member States, of the One Part, and the Republic of Singapore, of the Other Part. https://docs.eaeunion.org/docs/enus/01423247/iatc_04102019. Accessed 18 Feb 2020

[34] Eurasian Economic Union (2019b) Free Trade Agreement Between the Eurasian Economic Union and Its Member States, of the One Part, and the Republic of Singapore, of the Other Part. https://docs.eaeunion.org/docs/enus/01423247/iatc_04102019. Accessed 18 Feb 2020

[35] International Monetary Fund (2020) Data. http://data.imf.org/regular.aspx?key=61013712.

Accessed 28 Mar 2020

[36] Barisitz S, Radzyner A (2017) The New Silk Road, part II: implications for Europe. Focus On Eur Econ Integr Q4 (17):70-81

[37] Eurasian Economic Commission (2018) Tamozhennyy kodeks EAES vstupil vsilu [The EAEU Customs Code has entered into force]. http://www.eurasiancommission.org/ru/nae/new s/Pages/01-01-2018-1.aspx. Accessed 16 Dec 2019

[38] Lobyrev V, Tikhomirov A, Tsukarev T, Vinokurov E (2018) Belt And Road Transport Corridors: Barriers And Investments. EBD Centre Report 50. Eurasian Development Bank. https://eabr.org/upload/iblock/245/EDBCentre_2018_Report-50_TransportCorridors_Barriers-and-Investments_ENG.pdf. Accessed 27 January 2020
[39] World Bank (2020) Logistics Performance Index.

https://lpi.worldbank.org/international/aggregate d-ranking. Accessed 5 Feb 2020.

[40] Kostecka-Tomaszewska L, CzerewaczFilipowicz K (2019) Poland-A Gate to the EU or a Bottleneck in the Belt and Road Initiative. Eur Res Stud J XXII(4):472-492

[41] Freedom House (2019) Freedom in the World 2019. https://freedomhouse.org/report/countriesworld-freedom-2019. Accessed 9 Feb 2020

[42] Kolomeytseva A, Maksakova MA (2019) Integration Potential in Energy Sector: Eurasian Economic Union Case. Int $\mathrm{J}$ of Energy Economics and Policy 9(2):74-181

\section{Contribution of individual authors to the creation of a scientific article (ghostwriting policy)}

In this article, the goal formulation, methodology, literature review, SWOT analysis and conclusions are developed by both authors. Vectors of EAEU external strategy and the EAEU institutional extraregional integration was researched and developed by Dr. Agnieszka Konopelko. Research on the logistic and business aspects of the EAEU extraregional integration was carried out by Prof. Katarzyna Czerewacz-Filipowicz.

\section{Funding:}

This work was supported by the Ministry of Science and Higher Education of the Republic of Poland under Grant No. W / WIZ-INZ / 1 / 2019 and Grant No. W / WIZ-INZ / 1 / 2020.

\section{Creative Commons Attribution License 4.0 (Attribution 4.0 International, CC BY 4.0)}

This article is published under the terms of the Creative Commons Attribution License 4.0

https://creativecommons.org/licenses/by/4.0/deed.en US 